報文

\title{
ラムノリピッド型微生物バイオサーファクタント の界面化学的特性
}

\author{
石上 裕 $^{*}$ 蒲 康夫* $・$ 山口宗男 ${ }^{* *} \cdot$ 中原久恵 ${ }^{*}$ 鎌田俊雄 ${ }^{*}$

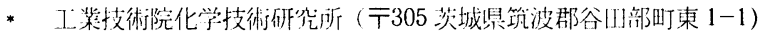

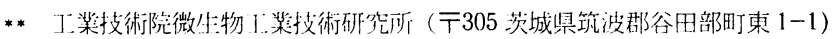

\section{Surface Active Properties of Rhamnolipids as Microbial Biosurfactants}

\author{
Yutaka ISHIGAMI, Yasuo GAMA, Muneo YAMAGLCl , Hisae NAKALARA, and Toshio KAMATA \\ * National Chemical Laboratoty for Industry \\ (1-1 IIgashi, Yatahe-machi, Tsukuba-gun, Ibaraki-ken) \\ ** Fermentation Research Institute \\ (1-1 Higashi, Yatabe-machi, Tsukuba-gun, Ibaraki-ken)
}

Sudies were carried out to evaluate the surface active properties of rhamnolipid B $[2-O-(2-$ $O$ - $\alpha$-decenoyl- $\alpha$-L-rhamnopyranosyl) $-\alpha-\mathrm{L}$-rhamnopyranosyl- $\beta$-hydroxydecanoyl- $\beta-$ hydroxydecanoic acid] and its precursor A as microbial biosurfactants produced by the hydrocarbon-assimilating bacterium, Pseudomonas aeruginosa BOP 100. The micelle formation of the sodium salts of rhamnolipids was confirmed by the detection of critical micelle concentration $\mathrm{s}(\mathrm{cmc})$ of $\mathrm{A}: 6.22 \times 10^{-5}, \mathrm{~B}: 1.50 \times 10^{-4} \mathrm{M}$ (fluorescence intensity of ANS) and by micellar weight determinations of A:38000, B: 7000 (light scattering), in spite of the bulky and complicated structures of the micelles, consisting of alternate hydrophobic and hydrophilic portions in contrast to synthetic surfactants. The $\gamma \mathrm{cmc}$ values of the sodium salts of $\mathrm{A}$ and $\mathrm{B}$ were $28 \mathrm{mN} / \mathrm{m}$, while their interfacial tension was 0.2 and $3.2 \mathrm{mN} / \mathrm{m}$ at the interface between $0.1 \%$ solution and kerosene. Moreover, highly efficient gross effects were also noted particularly in dispersing, emulsifying, foaming and penetrating action. From these findings rhamnolipids may be concluded to have large surface activity and polyfunctionality on the basis of the amphiphiles as membranous constituents.

\section{1 緒言}

Pseudomonas aeruginosa の発酵液中に各種の代謝 産物が含まれ，抗菌作用を示すことが 1930 年ころから 知られていた。Jarvis ら ${ }^{1)} 1949$ 年炭素源としてバ クトペプトンーグリセリンを用い; 発酵液中にラムノリ ピッド $2.5 \mathrm{~g} / \mathrm{L}$ を得, 結核菌に対する抗菌作用を報告 した。他に, 関連する研究もある ${ }^{2)}$, 3)。その後, 炭化 水素発酵の研究において, 炭化水素資化性のPseudomonas 属菌が炭化水素を菌体内へ取りこむためにラム ノリピッドを分泌して炭化水素を乳化し微小化すること が明らかにされた (4) 7)。こらの糖脂質は2 分子の 2
一ヒドロキシデカン酸からなるジラムノシルリピッド (R 1) とモノラムノシルリピッド ( R 2) であって, 生 産菌自身の生育あるい(呼吸を促進(7) 10), また抗菌

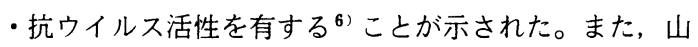
口ら ${ }^{11) ~ 13) ~}$ は炭化水素資化性菌として自然界から分離 したPseudomonas aeruginosa BOP 100 がnーパラ フィンを資化して Fig.-1 の構造の多鎖アルキル基と二 重結合を有する新種のラムノリピッドを産生することを 見いだし, 活性スラッジ法による炭化水素の分解処理 に対する促進効果を検討している。さらに, Wagner ら 14)，15)も R2 及び R4 の二種の新しいラムノリピッ ドを含むFig. -2 のラムノリピッド同族体を分離した。 


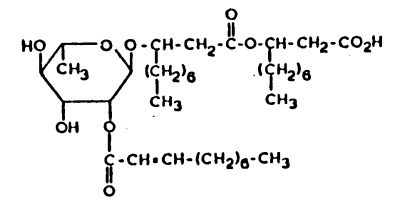

Rhamnolipid A

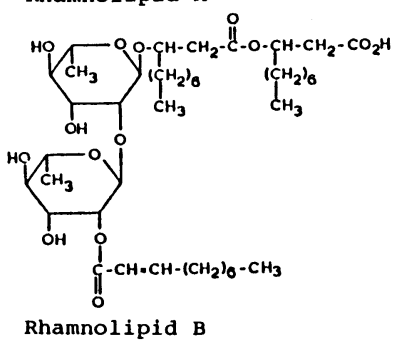

Fig.-1 Rhamnolipid A and B.

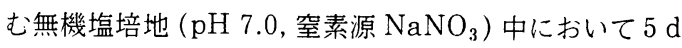
振上う培湌した。得られた発酵液を硫酸酸性とした後ジ エチルエーテル可溶分を抽出し, さらにシリカゲルカラ ムクロマトグラフィー(クロロホルム：メタノール，95: 5) で単離して二種のラムノリピッド $\mathrm{A}$ 及び $\mathrm{B}$ を得た。 さらに, ラムノリピッド A はカーボン処理により,ま た B はジエチルエーテルーnーヘキサン (8:2) から再結 晶することにより精製した。詳細は既報 ${ }^{11}$ ，12) に記し た。

\section{$2 \cdot 1 \cdot 2$ 試 薬}

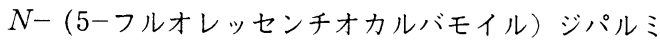
トイルーIーホスファチジルエタノールアミンはアメリ カ Molucular Probe 社製，8ーアニリノー1ーナフタレン スルホン酸ナトリウムは和光純薬工業㑣製の試薬を用い

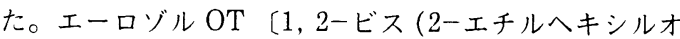<smiles>[R]OC(=O)CC(CC)OC1OC2CC(O)C(O2)C1O</smiles>

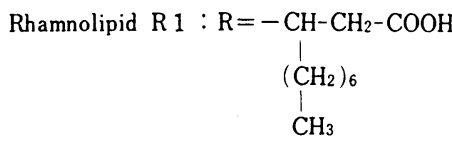

Rhamnolipid R $2: \mathrm{R}=\mathrm{H}$

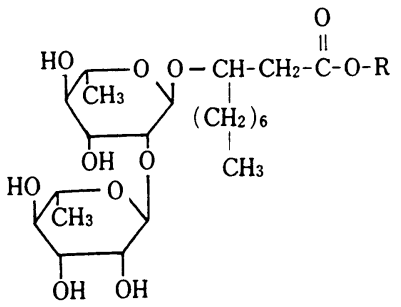

Rhamnolipid $\mathrm{R}_{3}: \mathrm{R}=-\mathrm{CH}-\mathrm{CH}_{2}-\mathrm{COOH}$ $\left.\stackrel{1}{(} \mathrm{CH}_{2}\right)_{6}$
1
$\mathrm{CH}_{3}$

Rhamnolipid R $4: \mathrm{R}=\mathrm{H}$

Fig.-2 Other four kinds of rhamnolipid homologues. ${ }^{14)}$

なお， $\mathrm{R} 1$ 及び $\mathrm{R} 3$ は伊藤ら ${ }^{6}$ の $\mathrm{R}-1$ 及び $\mathrm{R}-2$ 上同 一であり, R 1 R 4 の生産量は発酵液中最高 $15 \mathrm{~g} / \mathrm{L}$ であった。

さきに，筆者ら ${ }^{16)}$ はラムノリピッド $\mathrm{A}$ 及び $\mathrm{B}$ が $\mathrm{pH}$ に依存して分子集合形態を変換することを報告した。 本研究においては, 微生物バイオサーファクタント亡し てラムノリピッド A 及び B の界面化学的特性を明らか にすることにより, 生体膜成分として生体機能との関連 の解明を試みるとともに, また生分解性や安全性が大き く, かつ高付加価値の界面活性剂となる可能性につき検 討を加えた。

\section{2 実験}

\section{$2 \cdot 1$ 試 料}

$2 \cdot 1 \cdot 1$ ラムノリピッド

自然界から分離した炭化水素資化性菌Pseudomonas aeruginosa $\mathrm{BOP} 100$ を、 $5 \%$ の nーパラフィンを含
キシカルボニル） -1 -エタンスルホン酸ナ トリウム、以下 A. OT 之略称する〕は 和光純薬工業㑣製でアセトン及び石油エー テル不溶分を除いて精製した。硫酸ドデシ ルナトリウム (SDS)はイーストマンコ ダック社製試薬をそのまま用いた。ノニル フェニルポリ(オキシエチレン)（11）エー テル (NP-11) はライオン㑣製リポノック ス K を用いた。 $\alpha$ 一銅フタロシアニンブ ルー $(\alpha-\mathrm{Pc})$ は住友化学工業 (株) 製シ アニンブルーBB で, 平均粒子径 $2.0 \mu \mathrm{m}$, 比重 $1.45, \mathrm{pH} 7.0$ である。カーボンブ

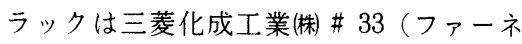
ス)飞, 平均粒子径 $0.025 \mu \mathrm{m}, \mathrm{pH} 8.5$, 表面 積 $95 \mathrm{~m}^{2} / \mathrm{g}$ である。その他市販試薬を用 いた。

水はイオン交換水のアルカリ性過マンガン酸カリウム 水溶液を蒸留した後, パイレックス製カラム $(30 \mathrm{~mm}$ $\phi$, 長さ $450 \mathrm{~mm}$, ガラス管のチップを充墴）にて再蒸 留したものを用いた。PBS 緩衝液は $1 \mathrm{~L}$ 当たり $\mathrm{NaCl}$ $18.0 \mathrm{~g}, \mathrm{KCl} 10.2 \mathrm{~g}, \mathrm{Na}_{2} \mathrm{HPO}_{4} 11.5 \mathrm{~g}$ 及び $\mathrm{KH}_{2} \mathrm{PO}_{4} 0.2$ $\mathrm{g}$ になるように蒸留水を加え，さらに塩酸にて $\mathrm{pH} 7.35$ に調整した。

\section{$2 \cdot 2$ 実験方法}

\section{$2 \cdot 2 \cdot 1$ 機器測定}

表面張力測定は Wilhelmy 型表面張力計 (島津 ST1 型）を用いて $30 \pm 0.5^{\circ} \mathrm{C}$ で行った。界面張力測定は Core-Labo 社（アメリカ）製スピニングドロップ式モ デル 500 界面張力测定装置を用いて $30 \pm 0.5^{\circ} \mathrm{C}$ で行っ た。蛍光強度による臨界ミセル濃度 $(\mathrm{cmc})$ の測定には, 8ーアニリノー1ーナフタレンスルホネート (ANS) を溶 媒 (PBS 緩衝液, $\mathrm{pH}$ 7.35) 中に溶解し. 島津蛍光分光 光度計 $R F-540$ 型を用いて励起光の波長 $390 \mathrm{~nm}$ にお 
いて $490 \mathrm{~nm}$ の蛍光強度がミセルの生成により急増す る濃度を求めた ${ }^{17)}$ 。光散乱測定は島津光散乱光度計 $\mathrm{P}$ $\mathrm{G}-21$ 型を用い, セミオクタゴナルセルにて $25^{\circ} \mathrm{C}$ 及び3 $5^{\circ} \mathrm{C}$ で測定した。 $\mathrm{d} n / \mathrm{d} c$ は島津示差屈折計 $\mathrm{DR}-1$ 型を 用いた。水溶液の光学的清浄净化に留意し, 原液は 60000 $\mathrm{g}$ で $1 \mathrm{~h}$ 遠心した。ガラス器具類はすべて特製の装置 を用いてアセトン蒸気で除じん(塵)処理を行った。詳細 は既報 ${ }^{18)}$.19) に述べたとおりである。

$2 \cdot 2 \cdot 2$ 界面活性

測定法の概略を以下に記す。詳細は当該文献を参照さ れたい。起泡力: 半微量改良 TK 法 ${ }^{20}$ によって测定し た。すなわち, 高さ $40 \mathrm{~cm}$, 直径 $70 \mathrm{~mm}$ のガラス製ジャ ケット付き円筒容器を垂直にセットし, 外とうの整温筒 には $30^{\circ} \mathrm{C}$ の湯を循環させ, 内側の $400 \mathrm{~mL}$ 容目盛付き 泡容器内に試料溶液 $5 \mathrm{~mL}$ を入れ。そして, 泡容器 の底の溶液内にさしこんだ空気吹き込み用ガラス管を除 いて, 泡容器内は外気から遮断されるとともに水 300 $\mathrm{mL}$ を眝留したアスピレーターに接続される。アスピ レーターの下端のピンチコックを開いて水を流下させる ことにより試料溶液内に空気が入って発泡するので．流 下終了直後 $(0 \mathrm{~min})$ から $5 \mathrm{~min}$ 経過後までの泡の容積 を読んだ。また, 泡安定性 $=〔(0 \mathrm{~min}$ の泡容 $-5 \mathrm{~min}$ 後 の泡容 $) \times 100 / 0 \mathrm{~min}$ の泡容〕より, 泡安定度も計算し て求めた。浸透力 ${ }^{21}$ ) : 厚さ $0.2 \mathrm{~cm}, 2 \times 2 \mathrm{~cm}$ の正方形 のフェルト及び木綿布（大和紡, 帆布 \#6) を試験片之 して用いた。 $30 \pm 1{ }^{\circ} \mathrm{C} に て$ 自然沈降法により試料溶液面 に布がふれた瞬間からストップウォッチを押して計時 し, 布が液面から完全に離れて沈降する瞬間までの秒数 を読んだ。分散力 ${ }^{22}$ ： 固体微粉末 $50 \mathrm{mg}$ を $30 \mathrm{~mL}$ 容 目盛付き試験管に取り, 試料溶液 $20 \mathrm{~mL}$ を加えて振之 う機で水平に振りまぜ, $30^{\circ} \mathrm{C} に て ~ 4 \mathrm{~h}$ 静置する。ついで 試験管の液面から $5 \mathrm{~mL}$ の目盛線までピペットの先端を 挿入し，その部分から $2 \mathrm{~mL}$ を吸い取り，別の試験管 に移す。これに $25 \mathrm{~mL}$ の水を加えた希釈液 (A)につい て積分球式へーズメーター（日本電色デジタル濁度計 $\mathrm{NDH}-20 \mathrm{D})$ を用いて測定し, 次式によって分散力を求 めた。

分散力 $(\%)=\left(T_{0}-T_{s}\right) \times 100 T_{s}$, ここで. $T_{0}$ : 被検溶 液 $2 \mathrm{~mL}$ に水 $25 \mathrm{~mL}$ を加えた水溶液の透過率。 $T_{s}$ : 上記 $(\mathrm{A})$ の透過率。乳化力 ${ }^{21)}: 30 \mathrm{~mL}$ 容の目盛付き試 験管に試料水溶液 $3 \mathrm{~mL}$ と灯油 $2 \mathrm{~mL}$ を入れ。振とう 機で振りまぜた後直ちに $95^{\circ} \mathrm{C}$ の恒温水槽に浸漬して時 間（振とう $5 \mathrm{~min}$ 後より $120 \mathrm{~min}$ 後まで）上よもに分 離油層, 乳化層及び分離水相を読み取り。油層中の乳化 油層の面積の百分率を求め, 乳化率 $(\%)$ として算出した。

\section{3 実験 結果}

\section{$3 \cdot 1$ ミセル形成と表（界）面張力低下作用}

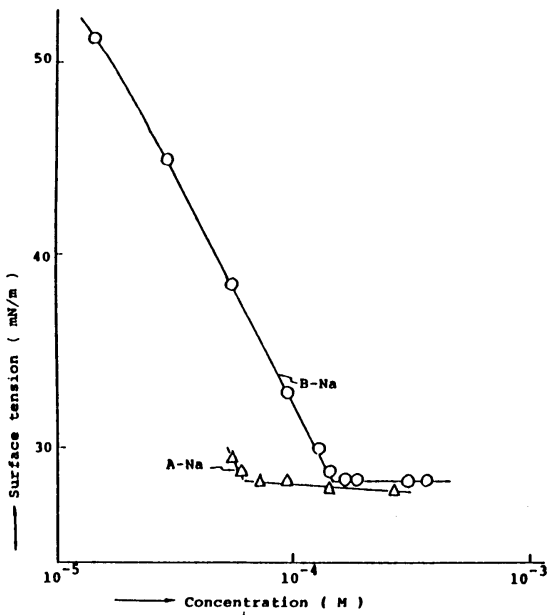

Fig.-3 Relation between surface tension and concentration of sodium salts of rhamnolipids in water at $30^{\circ} \mathrm{C}$.

ラムノリピッド $\mathrm{A}$ 及び $\mathrm{B}$ は水中で白濁した分散液を 与えるが、それぞれのナトリウム塩（以下 $\mathrm{A}-\mathrm{Na}$ 及び $\mathrm{B}$ - $\mathrm{Na}$ という）は水に透明に溶解した。表面張力対濃 度曲線を Fig. -3 に示した。ラムノリピッドナトリウム 塩はいず机も臨界ミセル濃度 $(\mathrm{cmc})$ を有し, ミセルを 形成することが明らかである。 $\mathrm{cmc}$ は $\mathrm{A}-\mathrm{Na}$ が 6.22 $\times 10^{-5} \mathrm{M}(0.042 \%), \mathrm{B}-\mathrm{Na}$ が $1.50 \times 10^{-4} \mathrm{M}(0.0124 \%)$ であり、 $\gamma_{\mathrm{cmc}}$ は両者ともおよそ $28 \mathrm{mN} / \mathrm{m}$ である。 $\mathrm{B}$ $-\mathrm{Na}$ について $\mathrm{cmc}$ 以下の単分子溶解領域における $\gamma /$ $\log c$ の勾配から求めた表面占有面積は $79.1 \AA^{2} / \mathrm{mole}$ cule であった。ラムノリピッドナトリウム塩はSDSや A. OTのような合成ア二オン界面活性剂より界面活性 の大きいことが明らかである。また, B-Na のように親 水基がジサッカリドとカルボキシラートで, 親水性が大 きく，かさ高い構造であってもミセル形成の妨げになっ ていないことがわかる。一方, $\mathrm{A}-\mathrm{Na}$ の $\mathrm{cmc}$ は $\mathrm{B}-\mathrm{Na}$ よりも小さく, HLB バランスに対応した予想どおりの 結果である。次に, 両親媒性蛍光色素 (ANS) を用い, $\mathrm{PBS}$ 緩衝液 $(\mathrm{pH}$ 7.35) 中における蛍光強度対濃度の関 係曲線を Fig. -4 に示した。 B-Na は $\mathrm{cmc}$ に対応する 亡見られる蛍光強度の立ち上がりが二段, $\mathrm{A}-\mathrm{Na}$ は三段 になっており，一段目のプレミセル(低次会合体) ${ }^{23)}$ を経 て大きなミセルを生成するプロセスが考えられる。三浦 ら24は蛍光強度測定により SDS の第二 $\mathrm{cmc}$ を見いだ しており， $\mathrm{A}-\mathrm{Na}$ の三段目， B- Na の二段目は第二 $\mathrm{cmc}$ に相当するものと思われる。Fig. -5 には $\mathrm{A}-\mathrm{Na}$ 及び $\mathrm{B}-\mathrm{Na}$ 水溶液の水と灯油または $n$-オクタンとの 界面張力対濃度曲線を示した。両者とも界面張力低下能 が大きく, 例えば $\mathrm{A}-\mathrm{Na}$ の $0.1 \%$ 水溶液は灯油一水界 面の界面張力を $0.2 \mathrm{mN} / \mathrm{m}$ に下げ, $\mathrm{B}-\mathrm{Na}$ の $0.05 \%$ 水 


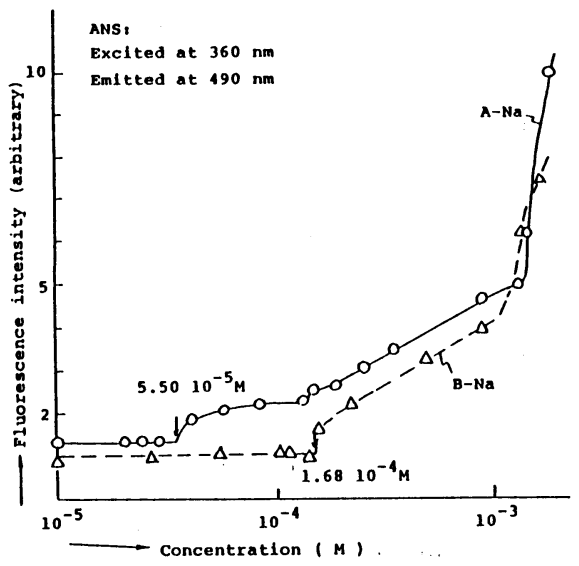

Fig.-4 Relation between fluorescence intensity and concentration of sodium salts of rhamnolipids in PBS buffer $(\mathrm{pH}$ 7.35) at $25^{\circ} \mathrm{C}$.

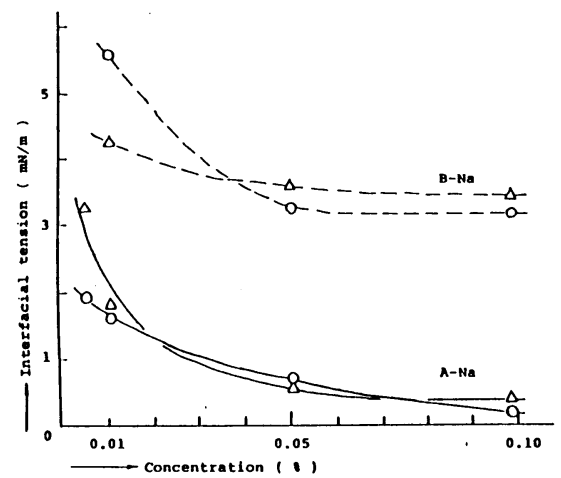

Fig.-5 Interfacial tension $v$ s. concentration plots at the interface between kerosene or octane and water at $30^{\circ} \mathrm{C}$.

溶液も $3.2 \mathrm{mN} / \mathrm{m}$ である。これらの値は台成界面活性 剂よりも著しく優れたものである。

さらに, $\mathrm{A}-\mathrm{Na}$ 及び B-Naのミセルの特性を知るた めに, PBS 緩衝液 ( $\mathrm{pH} 7.35)$ 中での光散乱測定を行っ た。Zimm プロット法から得た第二ビリアル係数 $\left(A_{2}\right)$ $=90 \times 10^{-4}$ を用いて補正を行い，また $\mathrm{d} n / \mathrm{d} c=0.25$ とし て一濃度近似法 ${ }^{18)}$ を適用して。 ミセル濃度 $\left(c-c_{0}\right)$ が $0.1 \%$ の時の散乱図形を Fig. -6 に示した。縦軸の切片 の逆数から重量平均の会合分子量 $\left(\mathrm{M}_{w}\right)$ を算出し. PBS ( $\mathrm{pH} 7.35)$ 中, $25^{\circ} \mathrm{C}$ で $\mathrm{A}-\mathrm{Na}: 38,000$ (会合数 56); B$\mathrm{Na}: 7,000$ （会合数 8.5) を得た。 $\mathrm{B}-\mathrm{Na}$ には散乱図形 に角度依存性がないので小さい会合体であり，他方 $\mathrm{A}$ 一Na は傾きがあるので会合体は大きく，また球状ミセ ルよりも形状がややだ円形に近いことが考えられる。さ

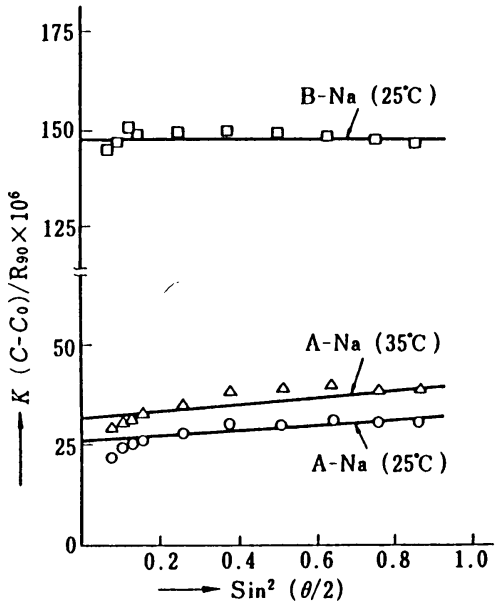

Fig. $-6 K\left(c-c_{0}\right) / R_{9_{0}} v s . \sin ^{2}(\theta / 2)$ plots of sodium salts of rhamnolipids $(0.1 \%)$ in the PBS buffer ( $\mathrm{pH} 7.35)$.

らに，いずれの曲線も低角度で下方に落ちこんでいるの で大きい会合体の共存が考えられる。Fig.-4において 各曲線の蛍光強度か濃度に依存して二つまたは三つに区 分できることから，この区分された領域に対応してミセ ルの大きさや形状が変化していくことを示すものと推定 される。さらに. $\mathrm{A}-\mathrm{Na}$ は $35^{\circ} \mathrm{C} て ゙$ 会合分子量が 31,000 に減少するので $\mathrm{A}-\mathrm{Na}$ 分子のカルボキシル基の親水性 が増大して会合数に影響を与え，ラムノース基による親 水性（水素結合による水との親和性）の減少の効果の小 さいことがわかる。

\section{$3 \cdot 2$ 界面化学的諸性質}

Table-1 に起泡力試験の結果を示した。起泡力及び 泡安定性ともに $0.1 \%$ 以下の低濃度でラムノリピッドナ トリウム塩の方が SDSやA. OTよりも優れていたが,

Table-1 Foaming properties of sodium salts of rhamnolipids.

\begin{tabular}{c|c|r|r|c}
\hline \multirow{2}{*}{ Surfactant } & Concn. & \multicolumn{2}{|c|}{$\begin{array}{c}\text { Foam volume } \\
(\mathrm{mL})\end{array}$} & Foam stability \\
\cline { 3 - 4 } & $(\%)$ & $\begin{array}{c}0 \min \\
(\mathrm{A})\end{array}$ & $\begin{array}{c}\overline{5} \min \\
(\mathrm{B})\end{array}$ & \multirow{2}{*}{$(\mathrm{B} / \mathrm{A}) \times 100(\%)$} \\
\hline $\mathrm{A}-\mathrm{Na}$ & 0.10 & 258 & 240 & 93 \\
$\prime \prime$ & 0.05 & 145 & 60 & 41 \\
$\prime \prime$ & 0.01 & 125 & 60 & 48 \\
$\mathrm{~B}-\mathrm{Na}$ & 0.10 & 275 & 250 & 91 \\
$\prime \prime$ & 0.05 & 268 & 185 & 69 \\
$\prime \prime$ & 0.01 & 252 & 130 & 52 \\
$\mathrm{SDS}$ & 0.50 & 237 & 130 & 54 \\
$\prime \prime$ & 0.10 & 54 & 9 & 17 \\
A. OT & 0.50 & 283 & 24 & 8 \\
$\prime \prime$ & 0.10 & 228 & 19 & 8 \\
\hline
\end{tabular}


Table-2 Penetrating properties of sodium salts of rhamnolipids.

\begin{tabular}{|c|c|c|c|}
\hline Surfactant & $\begin{array}{c}\text { Concn. } \\
(\%)\end{array}$ & \multicolumn{2}{|c|}{$\begin{array}{ll}\text { Sinking time } & (\mathrm{s}) \\
\text { for colton } & \text { for felt }\end{array}$} \\
\hline $\mathrm{A}-\mathrm{Na}$ & 0.10 & 29.6 & 20.2 \\
\hline " & $0.0 \overline{5}$ & 68.1 & 31.1 \\
\hline " & 0.01 & 766 & 308 \\
\hline $\mathrm{B}-\mathrm{Na}$ & 0.10 & 780 & 31.3 \\
\hline SDS & 0.50 & 8.6 & 52.3 \\
\hline " & 0.10 & 500 & 30.3 .2 \\
\hline A. OT & 0.50 & 1.2 & 0.8 \\
\hline " & 0.10 & 1.6 & 4.2 \\
\hline
\end{tabular}

泡のキメはSDSよりも粗であった。また，B-Naの方 が A-Na よりも起泡力や泡安定性が大きい。Table-2 には浸透力を示した。A. OT が抜群に優れているが, ラムノリピッドナトリウム塩も浸透作用を有しているこ とがわかる。また, $\mathrm{A}-\mathrm{Na}$ の方が $\mathrm{B}-\mathrm{Na}$ よりも浸透力 が大きい。これまで直鎖アルキル基を有する界面活性剂 は表面吸着濃度が大きく，起泡力が大きいよいわれてい るが, $\mathrm{A}-\mathrm{Na}$ 及び $\mathrm{B}-\mathrm{Na}$ はかさ高い多鎖構造を有する ので優れた起泡作用を説明できない。また、ジサッカリ ドの $\mathrm{B}-\mathrm{Na}$ がモノサッカリドの $\mathrm{A}-\mathrm{Na}$ 上同等以上の起 泡力之泡女定性を有する理由として, 糖基が踈水性を示 すとともにかさばらない配向構造をとることを仮定すれ ば理解できる。実際に糖類が疎水性を示す場合のあるこ 亡 ${ }^{25)}$ やヒドロキシル基の一部をメトキシル化して水素 結合を妨げるとかえって糖の親水性の増すことが知られ ている。例えば, セルロースは水に不溶であるが, ブド ウ糖単位の三つの遊離ヒドロキシル基のうち $1.3 \sim 2.6$ 個をメトキシル化したメチルセルロースは水に可溶とな $3^{26)}$ 。

Table-3には灯油に対する乳化力を示した。SDSよ りも大きい乳化力を有し, 表面張力低下能に対応してい るものと思われる。久塚ら”もラムノリピッド R1 が合 成非イオン界面活性剤よりも乳化作用の優れていること を示した。また， R1について多価アルコールを用いて 油分の乳化を行い, 乳化粒子径 $1 \mu \mathrm{m}$ 以下の安定な乳化 系を得ている ${ }^{27)}$ 。本研究のラムノリピッド $\mathrm{A}$ 及び $\mathrm{B}$ も乳化組成物の粒子系 $3 \mu \mathrm{m}$ 以下の安定な乳化物を得 $た^{28)}$ 。

難分散性の $\alpha-\mathrm{Pc}$ 及びカーボンブラックに対する分 散力を Table-4 に示した。二つの分散質に対して A$\mathrm{Na}$ 及び B-Na は良好な分散作用を示すが，特に $0.01 \%$ の低濃度においてさえも顕著な分散力を有している。 $\alpha-\mathrm{Pc}$ 及びカーボンブラックはよ゙ちらも疎水性表面を 有する。特に前者は著しく, 後者は製造時の燃焼工程や 酸化処理によって若干のヒドロキシル基やカルボキシル 基が存在する。それ故, $\mathrm{A}-\mathrm{Na}$ 及び $\mathrm{B}-\mathrm{Na}$ は $\alpha-\mathrm{Pc}$ の
Table-3 Emulsifying power of sodium salts of rhamnolipids for kerosene.

\begin{tabular}{c|cc}
\hline Surfactant & $0.50 \%$ & $0.10 \%$ \\
\hline $\mathrm{A}-\mathrm{Na}$ & 73 & 57 \\
$\mathrm{~B}-\mathrm{Na}$ & 96 & 54 \\
$\mathrm{SDS}$ & 87 & 70 \\
\hline
\end{tabular}

Table-4 Dispersing power of sodium salts of rhamnolipids.

[ $\alpha$-Cu phthalocyanine blue〕

\begin{tabular}{c|cc}
\hline Surfactant & $0.10 \%$ & $0.01 \%$ \\
\hline $\mathrm{A}-\mathrm{Na}$ & 44 & 36 \\
$\mathrm{~B}-\mathrm{Na}$ & 75 & 46 \\
SDS & 33 & 23 \\
NP-11 & 71 & 37 \\
Water & 7 & 7 \\
\hline
\end{tabular}

\begin{tabular}{c|cc}
\multicolumn{3}{c}{ [Carbon black] } \\
\hline & $0.10 \%$ & $0.10 \%$ \\
\hline $\mathrm{A}-\mathrm{Na}$ & 30 & 14 \\
$\mathrm{~B}-\mathrm{Na}$ & 23 & 23 \\
SDS & 4 & 3 \\
$\mathrm{NP}-11$ & 89 & 8 \\
Water & 2 & 2 \\
\hline
\end{tabular}

疎水表面上に三鎖の炭化水素部が疎水結合して $\alpha-\mathrm{Pc}$ 粒子に負荷電を与えるとともにラムノース基による粒子 表面の被覆効果もあるものと思われる。他方, カーボン ブラックに対しては粒子表面上の極性基と $\mathrm{A}-\mathrm{Na}$ や $\mathrm{B}$ - $\mathrm{Na}$ の極性基との相互作用を介する分散作用と炭化水 素鎖の疎水結合による分散作用が同時に働くため, カー ボンブラックに対する分散力は大きくならないことが考 えられる。なお, ラムノリピッド A及びBの $0.5 \%$ 水溶 液を水酸化ナトリウムで $\mathrm{pH} 7.0$ に調整し, 成人女性 15 人に対して皮膚刺激試験を行ったところ, 皮膚刺激性 は全く認められなかった28)。

\section{4 考察}

ラムノリピッド $\mathrm{A}$ 及び $\mathrm{B}$ のバイオサーファクタント としての化学構造をみると, 親水基は 1 ないし 2 個のラ ムノースと 1 個のカルボキシル基であり，他方親油基は 大きく分けて二鎖アルキル型構造であって，そのうちの 一鎖はデセノイル基, もう一鎖は二本のへプチル基を分 枝した2-ヒドロキシプロピオニルプロピオン酸で糖基 の反対末端にはカルボキシル基を有する。このように, ラムノリピッドは親油基及び親水基がかさ高く，しかも 両者が入り組んだ (interpenetrated) 構造である。従来 から, 胆汁酸, カゼイン及びレシチンなどの生体界面活 性剂やショ糖脂肪酸エステル，スパン及びトウィーンな 
ど天然物改質系界面活性剂が知られているが, 合成界面 活性剂の構造別ないし合成法に基づく分類 29.3013 には 入りにくい。既に著者らが報告した多塩基酸型バイオ サーファクタントのスピクリスポール酸やアガリチン 酸 $^{311}$, さらにスクシノイルトレハロースリピット32) も 同様である。

本研究のラムノリピッド $\mathrm{A}$ 及び $\mathrm{B}$ とは別に見いださ れた四種のラムノリピッド同族体 (Fig.-2)について. Wagner ら ${ }^{14)}$ は表面張力 $25 \sim 31 \mathrm{mN} / \mathrm{m}$, 界面張力 1 $\mathrm{mN} / \mathrm{m}$ 以下, $\mathrm{cmc}$ として 0.002 0.02\% との結果を得 ている。 R 4 は $2 \mathrm{~mol}$ の糖鎖とデカン酸からなる化学 構造を有するので最も親水性が大きく、他方 $\mathrm{R} 1$ が最も 界面活性であることが予期さ机るが，実験結果を見る之 いずれも界面活性が大きく, 四者の間の性能の差は小さ い。詳細に比較すると, (1)糖の数だけが異なる R 1 と $\mathrm{R} 3$ 及びR 2 とR 4 とを比べると糖が $1 \mathrm{~mol}$ から 2 $\mathrm{mol}$ に増すと界面張力低下能が若干増大する, (2)デカ ノイル基の数だけが異なる $\mathrm{R} 1$ と R 2 及び $\mathrm{R} 3$ と $\mathrm{R} 4$ とを比べるとデカノイル基が $1 \mathrm{~mol}$ から $2 \mathrm{~mol}$ に増す と $\mathrm{cmc}$ が増大する，との結果であった。なお，表面張 力及び界面張力の大きさを界面活性の指標之して見る之 乳化分散作用や起泡作用の大きいことが考えら机る。実 験結果は予想どおりで，浸透作用もあり，しかも $0.01 \%$ 程度の低濃度でそれらの作用を充分に発揮しうることが わかった。

つぎに, ラムノリピッド型バイオサーファクタントが 石油微生物 (Pseudomonas 属菌) の代謝産物として生 物活性を示す点に注目したい。ラムノリピッドは酸性側 からアルカリ側まで幅広い水溶性領域を有するが, $\mathrm{pH}$ 7.0 の Pseudomonas 属菌の生育条件においてラムノリ ピッドは中和塩になっており菌体外に分泌されて菌体近 傍の炭化水素を微小化し, かつ油滴の外周に吸着して油 滴表面を細胞膜内の HLB に近づけて菌体内への取りこ みを容易にしている4 ものと考えられる。ラムノリピッ ドは原核微生物 (Pseudomonas 属菌) の細胞膜成分亡 して菌の生育に寄与していることが推定されるが、牛乳 の脂肪球が乳せん細胞由来の細胞膜成分によって乳濁液 を安定に保持している例 ${ }^{33}$ )などを考え合わせると, 一 般に細胞膜成分がその界面活性に基づいて各種の生物活 性の発現に関与するもの之思わ机る。こうした観点から， ラムノリピッドナトリウム塩の分子集合体は濃度に依存 して小さいプレミセルから大きいミセル, さらにはベシ クルやコアセルベートへと成長でき，しかも $\mathrm{pH}$ に依存 して容易に分子集合形態の変換を行うことが可能な融通 性をも併せ持つことが理解できる。このようにして生体 膜成分である微生物バイオサーファタントの多機能性と 環境適合性の一端を明らかにすることができた。

(昭和 62 作 4 月 20 日受理)

\section{文献}

1) E. G. Jarvis, M. J. Johnson, J. Am. Chem. Soc., 71, 4124 (1949)

2) G. Ilauser, M. L. Karnovsky, J. Bacteriol., 68, 645 (1954)

3) J. R. Edwards, J. A. Hayashi, Arch. Biochim. Biophys., 111, 415 (1965)

1) K. Hisatsuka, 'T. Nakahara, N. Sano, K. Yamada, Agr. Biol. Chem., 35, 686 (1971)

5) K. Hisatsuka, T. Nakahara, K. Yamada, Agr. Biol. Chem., 36, 1361 (1972)

6) S. Itoh, H. Honda, F. Tomita, T. Suruki, J. Antibiotics, 14, 855 (1971)

7) S. Itoh, T. Suzuki, Agr. Biol. Chem., 36, 2233 (1972)

8) 中原忠第, 発酵之工業, 40, 1019 (1982)

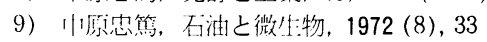

10) T. Nakahara, K. Ilisatsuka, Y. Minoda, J. Ferment. Technol., 59, 415 (1981)

11) M. Yamaguchi, A. Satoh, A. Yukuyama, Chem. Ind. London, 1976, 741

12）山四宗男, 佐藤昭雄, 行山燠, 微工研趣, No. 51,35 (1978)

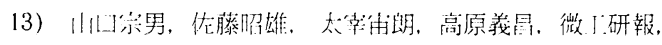
No. 51, 51 (1978)

11) C. Syldatk, S. Lang, U. Matulovic, F. Wagner, Z. Naturforsch., 40 c, 61 (1985)

15) C. Syldatk, S. Lang, F. Wagner, Z. Naturforsch. $40 c, 51$ (1985)

16) Y. Ishigami, Y. Gama, H. Nagahora, M. Yamaguchi, H. Nakahara, T. Kamata, Chem. Lett., 1987, 763

17) M. J. Ortner, R.H. Sik, C. F. Chignoll, Molecular Pharmacol., 15, 179 (1979)

18) T. Kamata, H. Nakahara, J. Colloid Interface Sci., 43, 89 (1973)

19）石上裕, 楢崎英男, 油化学, 25, 335 (1976)

20）朴村㕲一郎, 失野 弥, 油化敩, 11, 138 (1962)

21) 不上 裕, 油化学, 26, 781 (1977)

22）石上䈶, 鈴木 茂, 山崎信助, 色材, 56,449 (1983)

23）不上，裕，東厂試二ュース・化学: T業資料，7 (4), 72 (1972)

24) Y. Kubota, M. Kodama, M. Miura, Bull. Chem. Soc. Jpn., 46, 100 (1973)

25）謝名堂兒信，化学と生物，22，29 (1984)

26）中村亦夫監修。“水溶性高分子” 化学工業日報社(1973), p. 60 (岩田)； p. 285 (芝崎)

27）公開特許 昭 59-39338

28）柴山，宇治，石上ら，特許出愿中

29）佐々朴垍隆，油化学，17, $116(1968)$

30) 桑忖常彦, 油化学: 14, 483 (1965)

31）石上裕, 山崎信助, 化技研報, 80, 231 (1985)

32）石上裕, 鈴木 笺, 船田正, 茅野雅子, 内田康一, 田㴊武士, 油化学, 36, No. 11 (1987) 印刷中

33）伊藤敞敏, 中西武雄, 農化, 48, 239 (1974) 